VOL. 1 OKTOBER (2018) : 49-53

p-ISSN: 2621-1203 | https://doi.org/10.32665/james.v1iOctober.31 | e-ISSN: 2621-1211

\title{
EKSPERIMENTASI PEMBELAJARAN E-LEARNING TERHADAP PRESTASI BELAJAR MATEMATIKA PADA POKOK BAHASAN ALJABAR DI SMP SE-KABUPATEN BOJONEGORO
}

\author{
Dian Nurul Safitri ${ }^{1}$ \\ IKIP PGRI Bojonegoro, dian.nurul88@ gmail.com ${ }^{1}$ \\ Received : 28 Agustus 2018, Revised : 1 Oktober 2018, Accepted : 17 Oktober 2018 \\ (c) Mathematics Education Unugiri 2018
}

\begin{abstract}
This research aims to determine whether there is a positive influence of $e$-learning on mathematics learning achievement on the algebra subjects in junior high schools in Bojonegoro district. This research is a quasiexperimental research with two research variables. The dependent variable in this research is the mathematics learning achievement and the independent variable from this research is the learning model. This research was analyzed by using t-test with the analysis prerequisite test that is the normality test with the liliefors method and homogeneity test with the $\mathrm{F}$ test method. The result of this research is that there is a positive influence of e-learning on mathematics learning achievement on algebra subjects in junior high school in Bojonegoro district.
\end{abstract}

Keywords : E-learning, learning achievement

\begin{abstract}
Abstrak
Penelitian ini bertujuan untuk mengetahui ada tidaknya pengaruh positif pembelajaran e-learning terhadap prestasi belajar matematika pada pokok bahasan aljabar di SMP sekabupaten Bojonegoro. Penelitian ini merupakan penelitian eksperimental semu dengan dua variabel penelitian. Variabelterikat dalam penelitian ini adalah prestasi belajar matematika dan variabelbebas dari penelitian ini adalah model pembelajaran. Penelitian ini dianalisis menggunakan uji t dengan uji prasyarat analisis yaitu uji normalitas dengan metode liliefors dan uji homogenitas dengan metode uji $\mathrm{F}$. Hasil penelitian ini adalah terdapat pengaruh pengaruh positif pembelajaran e-learning terhadap prestasi belajar matematika pada pokok bahasan aljabar di SMP sekabupaten Bojonegoro.
\end{abstract}

Kata Kunci : Pembelajaran e-learning, prestasi belajar

\section{Pendahuluan}

Pendidikan merupakan pondasi kemajuan suatu bangsa. Bangsa yang memiliki pendidikan yang baik akan menjadi bangsa yang lebih maju. Pendidikan merupakan suatu proses yang dinamis dimana setiap saat mengalami perkembangan. Perkembangan dalam dunia pendidikan ditunjukkan dengan berkembanganya berbagai macam metode pembelajaran dan juga fasilitas pendidikan. Perkembangan pendidikan tentunya tidak lepas dari perkembanganteknologi yang terjadi pada saat ini. Pada saat ini hampir di seluruh bidang kehidupan tidak lepas dari teknologi. Rian [5] menyebutkan bahwa teknologi merupakan elemen penting dalam segala aspek kehidupan salah satunyanya pendidikan. Teknologi telah memberikan banyak pengaruh pada pendidikan. Teknologi telah menyediakan banyak kemudahan dalam proses pendidikan. Salah satu pemanfaatan teknologi dalam pendidikan adalah dengan menggunakannya sebagai model pembelajaran melalui pembelajaran e-learning. 
Pendidikan pada saat ini terus mengalami perubahan peserta didik dituntut untuk mempelajari banyak mata pelajaran dalam satu hari. Pada kondisi ini sangat memungkinkan peserta didik mencapai titik jenuh atau lelah, sehingga pelajaran yang disampaikan mungkin tidak bisaditerima dengan baik oleh peserta didik. Pembelajaran di sekolah sangat mungkin tidak terserap secara maksimal. Tentu saja hal ini nantinya akan berakibat terhadap menurunnya prestasi belajar peserta didik. Sementara apabila peserta didik telah sampai di rumah dan membuka kembali catatannya mereka kesulitan untuk memahami pembelajaran, karena tidak adanya pembimbing. Hal ini menimbulkan kesalahan belajar sehingga pemahaman peserta didik pun salah. Apabila hal seperti ini terus dibiarkan akan berakibat lebih buruk.

Dari permasalahan tersebut pembelajaran dengan menggunakan e-learning bisa menjadi solusi yang tepat. Pembelajaran e-learning menggunakan konsep pembelajaran jarak jauh yang tidak terbatas, waktu dan tempat pelaksanaannya. Peserta bebas mengakses dan memutar kembali materi dan tutorial yang mereka dapat kapanpun dan dimanapun yang mereka bisa. Dengan demikian waktu yang terbatas di sekolah tidak lagi menjadi batasan. Menurut Sriwihajriyah [6] e-learning merupakan pembelajaran dengan menggunakan media teknologi informasi dan komunikasi. Sementara Anam [2] mengemukakan bahwa e-learning sistem pembelajaran elektronik merupakan pembelajaran dengan menggunakan bantuan peralatan elektronik termasuk mengemas materi dalam CD-ROM.

Pendidikan dengan menggunakanelearning bisa dilakukan dengan banyakcara, baik melalui internet atau dengan memanfaatkan media elektronik yang lain. Pembelajaran e-learning adalah sebuah model dimana dalam sebuah pembelajaran melibatkan atau menggunakan alat bantu teknologi. Benson dalam Moore [4], menyebutkan bahwa e-learning bukan hanya penyampaian materi melalui CD-ROM, internet, atau intranet tetapi juga termasukpenyampaian materi melalui audio, video tape, penyiaransatelit dan juga melalui saluran televisi. Urdan dan Weggen dalam Anderson [1] pembelajaran dengan $e$ learning adalah pembelajaran yang dalam penyampaian materi ajar menggunakan media elektronik, misalnya internet, intranet, ekstranets, satelitpenyiaran, audio /video tape, TV interaktif dan CD-ROM. Australian National Training Authority dalam Anderson [1] bahwa e-learning adalah konsep yang lebih luas dari online-learning, meliputi penggunaan seluruh media elektronik yang ada untuk penyampaian pembelajaran dan pelatihan agar lebih fleksibel.

Pembelajaran e-learning dalam penelitian ini adalah pembelajaran dengan menggunakan alat bantu CD-ROM dimana dalam CD ROM tersebut terdapat tutorial dan materi pembelajaran. CD-ROM dibagikan kepada masing-masing peserta didik sehingga setiap peserta didik hanya perlu membuka CDROM tersebut untuk membuka kembali pelajaran yang telah didapat.

Penelitian ini bertujuan untuk mengetahui apakah terdapat pengaruh positif penggunaan pembelajaran e-learning terhadap prestasi belajar matematika pada pokok bahasan aljabar pada pesertadidik di SMP sekabupaten Bojonegoro.

\section{Metode Penelitian}

Penelitian ini merupakan penelitian eksperimental, dengan membandingkan dua kelompok peserta didik, yaitu kelompok eksperimen sebanyak 88 orang, dan kelompok kelompok control sebanyak 87 orang. Pada kelompok eksperimen peserta didik diajar menggunakan model pembelajarane-learning, sedangkan pada kelompok kontrol peserta didik diajar menggunakan model pembelajaran langsung. Penelitian ini mengambil populasi seluruh peserta didik SMP sekabupaten Bojonegoro. Sampel dari penelitian ini adalah peserta didik yang memiliki kemampuan sama yaitu SMP Negeri Temayang, SMP Negeri Dander, dan SMP Negeri 4 Bojonegoro. Masing-masing sekolah akan diambil dua 
kelas, kelas pertama sebagai kelas eksperimen, dan kelas yang kedua sebagai kelas kontrol. Sampel ini diperoleh dengan cara cluster random sampling, metode ini merupakan salah satu metode pengambilan sampel secara random tetapi tidak berdasarkan individu, melainkan berdasarkan sekelompok individu. Penelitian ini dilakukan melalui proses pembelajaran di masing-masing kelompok dengan model pembelajaran yang ditentukan. Proses pembelajaran dilakukan selama 6 kali pertemuan, pembelajaran dilakukan pada pelajaran matematika pada pokok bahasan aljabar.

Metode pengumpulan data pada penelitian ini dilakukan dengan dua metode, Metode yang pertama adalah metode dokumentasi, metode ini digunakan untuk mencari nilai yang telah dimiliki peserta didik sebelumnya yang nantinya akan digunakan untuk mengukur keseimbangan. Pengukuran keseimbangan ini diperlukan agar peneliti mengetahui bahwa sebelum dilakukan penelitian peserta didik dalam keadaan seimbang, sehingga hasil yang diperoleh setelah penelitian adalah murni karena perlakuan yang diberikan. Metode kedua adalah metode tes, metode tes ini digunakan untuk mengetahui nilai prestasi peserta didik pada pokok bahasan aljabar. Tes yang digunakan merupakan tes obyektif yang berbentuk pilihan ganda.Tes yang digunakan adalah tes yang telah diuji validitas, daya beda dan tingkat kesukaran serta reliabilitas, sehingga testersebut mampu untuk mengukur dan membedakan hasil belajar peserta didik. Nilai tes ini selanjutnya digunakan sebagai nilai prestasi belajar peserta didik. Nilai inilah yang digunakan untuk analisis data dengan metode statistik parametris.

Ujistatistik yang digunakan adalah uji t. Uji ini digunakan untuk analisis data nilai peserta didik sebelumnya sebagai data untuk uji keseimbangan, dan data nilai prestasi yang digunakan sebagai data untuk ujihipotesis. Pada uji diperlukan uji prasyarat yaitu uji homogenitas dan uji normalitas. Uji homogenitas dilakukan dengan menggunakan uji F, Sedangkan uji normalitas dilakukan dengan menggunakan metode liliefors. Dari uji inilah akan dirumuskan hasil penelitian yang dilakukan.

\section{Hasil Penelitian}

Penelitian ini dilakukan dengan pembelajaran dimasing-masing kelas selama 6 kali pertemuan. Setelah dilakukan pembelajaran dengan model pembelajaran $e$ learning dan model pembelajaran langsung. Sebelum pembelajaran dimulai peneliti mengumpulan data nilai peserta didik untuk digunakan sebagai data keseimbangan. Setelah pembelajaran Peserta didik di uji dengan tes tulis dengan soal-soalobjektif. Soal yang harus dikerjakan sebanyak 25 soal. Nilai dari tes tersebut selanjutnya dianalisis dengan uji statistik yang telah ditentukan sebelumnya yaitu ujit dan syaratnya.

Setelah dilakukan analisis data pada nilai awal untuk data keseimbangan didapat nilai sebagai berikut: untuk uji normalitas kelompok eksperimen dengan liliefors diperoleh $\mathrm{L}_{\mathrm{obs}}$ adalah 0,0644 nilai ini lebih kecil dari nilai

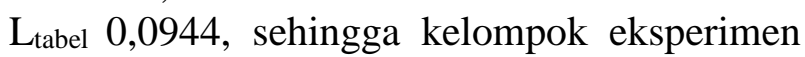
dinyatakanberasal dari populasi yang berdistribusi normal. Sedangkan pada kelompok kontrol diperoleh nilai $\mathrm{L}_{\text {obs }}$ adalah 0,0844 nilai ini juga lebih kecil dari nilai $\mathrm{L}_{\text {tabel }}$ 0,0950 sehingga kelas kontrol juga dinyatakan berasal dari populasi yang berdistriusi normal. Sementara setelah dilakukan perhitungan untuk mencari homogenitas variansi di dapat nilai uji $\mathrm{F}_{\text {obs }}$ adalah 1,1124, sedangkan nilai $\mathrm{F}_{\text {tabel }}$ adalah 1,4239 dari hasil tersebut dapat dilihat bahwa nilai $F_{\text {obs }}<F_{\text {tabel }}$ sehingga dapat disimpukan bahwa variansi data-data tersebut adalah homogen. Setelah data-data tersebut dinyatakan normal dan homogen selanjutnya data-data tersebut dihitung nilai keseimbangannya dengan menggunakan uji $t$. Hasil dari uji $\mathrm{t}$ diperoleh bahwa nilai $\mathrm{t}_{\mathrm{obs}}$ 0,6642 nilai ini lebih rendah dari nilai $t_{\text {tabel }}$ yaitu 1,9736. Dari hasil tersebut disimpulakan bahwa kedua kelompok eksperimen dan kelompok kontrol adalah seimbang. Hasil 
tersebut menunjukkan bahwa kedua kelompok tersebut bisadijadikan sampel untuk penelitian.

Selanjutnya kedua kelompok diberikan perlakuan dengan memberikan pembelajaran dengan menggunakan model pembelajaran langsung dan dengan menggunakan model pembelajaran e-learning. Pembelajaran ini dilakukan selama 6 kali pertemuan. Setelah pertemuan mencukupi selanjutnya peserta didik diberikan tes berupa tes pilihan ganda sejumlah 25 soal. Hasil dari tes yang dilakukan selanjutnya diolah dan dianalisis menggunakan uji t. Hipotesis dalam penelitian ini adalah dengan menggunakan model pembelajaran $e$ learning terhadap prestasi belajar matematika pada pokok bahasan aljabar pada peserta didik SMP sekabupaten Bojonegoro.

Sebelum data diolah dengan menggunakan uji t, terlebih dahulu data-data tersebut diuji normalitas dan homogenitasnya. Dari perhitungan yang telah dilakakukan didapat nilai Lobs untuk kelompok eksperimen adalah 0,0780 sedangkan nilai $\mathrm{L}_{\text {tabel }}$ diperoleh 0,944 sehingga dilai $\mathrm{L}_{\mathrm{obs}}<\mathrm{L}_{\text {tabel, }}$ kesimpulan yang diperoleh adalah kelompok eksperimen berasal dari populasi yang berdistribusi normal. Pada kelompok kontrol dilakukan analisisnormalitas dengan cara yang sama diperoleh nilai $\mathrm{L}_{\text {obs }}$ adalah 0,0668 nilai ini lebih kecil dari $\mathrm{L}_{\text {tabel }}$ 0,095, sehingga kelompok kontrol juga berasal dari populasi yang berdistribusi normal. Setelah data prestasi atau tes dinyatakan normal selanjutnya dilakukan analisishomogenitas dengan menggunakan uji F. setelah dilakukan analaisis didapat nilai $F_{o b s}$ adalah 1,1262 nilai ini lebih kecil dari $F_{\text {tabel }}$ 1,1439 sehingga dapat disimpulakan kalau data-data tersebut homogen. Setelah data-data dinyatakan normal dan homogen selanjutnya dilakukan analisis hipotesis dengan menggunakan uji t. Hasil yang diperoleh dari analisis uji t, diperoleh nilai $t_{\text {obs }}$ adalah 3,8236 . Nilai $t_{o b s}$ tersebut dari $t_{\text {tabel }} 1,9736$ sehingga $\mathrm{H}_{0}$ ditolak sehingga hipotesis yang berbunyi ada pengaruh positif model pembelajaran dengan menggunakan model pembelajaran e learning terhadap prestasi belajar matematika pada pokok bahasan aljabar pada peserta didik SMP sekabupaten Bojonegoro terbukti.

Keefektifan model pembelajaran mandiri dengan e-learning dibanding dengan model pembelajaran langsung dalam meningkatkan nilai prestasi belajar matematika menunjukkan bahwa peserta didik yang dalam proses pembelajaran yang kurang mengerti dalam sekali atau dua kali penjelasan akan memutar ulang CD-ROM seberapa kalipun peserta didik mau, sehingga pembelajaran akan lebih bisa dimengerti peserta didik. Sementara peserta didik yang diajar dengan model pembelajaran langsung, dengan keterbatasan guru yang tidak mungkin memenuhi keinginan peserta didik untuk selalu mengulang-ulang penjelasan materi kepada masing-masing peserta didik. Keefektifan model pembelajaran mandiri dengan e-learning ini sesuai dengan penelitian yang dilakukan Kranzow dan Hyland [3], yang dalam penelitiannya menyebutkan bahwa teknologi telah membawa banyak solusi dari masalah pendidikan yang terjadi, dan juga pembelajaran menjadi lebih efisien dan lebih membawa keuntungan dan kelebihan. Selain itu penelitian yang dilakukan oleh Suharyanto [7] pembelajaran dengan e-learning mampu meningkatkan prestasi belajar.

Pembelajaran dengan menggunakan $e$ learning juga mampu menyelesaikan masalah pembelajaran berkenaan dengan keaktifan peserta didik di kelas. Peserta didik yang biasanya hanya mendengarkanlewatpenjelasan dari guru, dapat memanfaatkan CD-ROM yang telah diberikan dengan memutar materi yang dia kehendaki. Melalui pembelajaran dengan $e$ learning peserta tidak lagi dibatasi oleh waktu untuk belajar dari guru meskipun tidak secara langsung. CD-ROM yang telah berisi materi dan tutorial tentang aljabar telah membantu peserta didik untuk mengatasiketidakmampuan mereka saat berada di kelas. Dengan demikian pembelajaran pun akan lebih maksimal. Pembelajaran yang maksimal telah meningkatkan prestasi belajar peserta didik. 


\section{Kesimpulan}

Dari penelitian ini dapat disimpulkan bahwa model pembelajaran e-learning memberikan pengaruh positif terhadap prestasi Matematika peserta didik SMP khususnya pada pokok bahasan aljabar.

\section{Referensi}

[1] Anderson, J, IT, E-Learning and Teacher Development, International Journal, 5 (2005) 1-14.

[2] Anam, N, Pengembangan Pembelajaran Berbasis E-Learning Perspektif Alessi \& Trollip, Al Qodiri, 5 (2013) 17- 31

[3] Kranzow, J., Hayland, N, Faculty and Student Views of Using Digital Tools to Enhance Self-Directed Learning and Critical Thinking. International Journal of Self-Direct Instructed Learning, 8 (2011) 11-27.
[4] Moore, J. L., Deane, C. D., Galyen, K, Elearning, Online Learning, and Distante Learning Environments: Are They the Same?, Internet and Higher Education, 11 (2011) 129-135

[5] Rian, Pentingnya Teknologi dalam Kehidupan sehari-hari, diambil dari https://lensa.univ-ekasakti-pdg.ac.id/84/ pentingnya-teknologi-dalam-kehidupanseharihari.html pada tanggal 6 Januari 2018

[6] Sriwihajriyah, N., Ruskan, E. L., Ibrahim, A, Sistem Pembelajran dengan E-Learning untuk Persiapan Ujian Nasional pada SMA Pusri Palembang. Jurnal Sistem Informasi, 4 (2012) 450-467.

[7] Suharyanto, Mailangkay,A.B, Penerapan E-Learning sebagai Alat Bantu Mengajar dalam Dunia Pendidikan. Jurnal Ilmiah Widya, 3 (2016). 
